\title{
Influence of root embedment material and periodontal ligament simulation on fracture resistance tests
}

\section{Influência do material de inclusão e da simulação do ligamento periodontal nos ensaios de resistência à fratura}

\author{
Carlos José Soares* \\ Eliane Cristina Gava Pizi** \\ Rodrigo Borges Fonseca*** \\ Luis Roberto Marcondes Martins ${ }^{* * * *}$
}

\begin{abstract}
The aim of this study was to evaluate the influence of the embedment material and periodontal ligament simulation on fracture resistance of bovine teeth. Eighty bovine incisor teeth were randomized into 8 groups $(n=10)$, embedded in acrylic or polystyrene resin using 4 types of periodontal ligament simulation: 1 - absence of the ligament; 2 - polyether impression material; 3 - polysulfide impression material; 4 - polyurethane elastomeric material. The specimens were stored at $37^{\circ} \mathrm{C}$ and $100 \%$ humidity for 24 hours. Specimens were submitted to tangential load on the palatal surface at $0.5 \mathrm{~mm} /$ minute crosshead speed until fracture. The fracture modes were analyzed as follows: 1 - coronal fracture; 2 - cemento-enamel junction fracture; 3 - partial root fracture; 4 - total root fracture. Statistical analyses by two-way ANOVA and Tukey's test were applied $(\mathrm{p}<0.05)$. The results showed that root embedment method and periodontal ligament simulation have a significant effect on fracture resistance. Artificial periodontal ligament modified the fracture modes.
\end{abstract}

DESCRIPTORS: Fracture resistance; Periodontal ligament; Tooth root; Cementoenamel junction.

RESUMO: O objetivo deste estudo foi avaliar a influência do material de inclusão e da simulação de ligamento periodontal na resistência à fratura de dentes bovinos. Oitenta incisivos bovinos foram divididos em 8 grupos $(n=10)$ e, então, incluídos em cilindros com dois materiais, resina acrílica ou resina de poliestireno, usando-se quatro tipos de simulação do ligamento periodontal: 1 - ausência do ligamento; 2 - material de moldagem à base de poliéter; 3 - material de moldagem à base de polissulfeto; e 4 - material elastomérico à base de poliuretano. As amostras foram armazenadas em $100 \%$ de umidade a $37^{\circ} \mathrm{C}$ por 24 horas e então submetidas a carregamento tangencial na superficie palatina com velocidade de $0,5 \mathrm{~mm} / \mathrm{minuto}$ até a fratura. Os padrões de fratura foram analisados de acordo com: 1 - fraturas coronais; 2 - fratura da junção esmalte-cemento; 3 - fratura parcial da raiz; 4 - fratura radicular total. A análise estatística empregou análise de variância fatorial e teste de Tukey $(p<0,05)$. Os resultados mostram que o método de inclusão e a simulação do ligamento periodontal tiveram efeito significativo na resistência à fratura. O ligamento periodontal artificial modificou os padrões de fratura.

DESCRITORES: Resistência à fratura; Ligamento periodontal; Raiz dentária; Colo do dente.

\section{INTRODUCTION}

A great number of factors can influence the clinical behavior of indirect and direct adhesive restorations. Cavity preparation design ${ }^{9}$, the technique and materials for fixation of the restoration ${ }^{7}$ and mainly the restorative material composition may influence the fracture resistance of these restorations $\mathrm{s}^{6,8,9,25}$. The ability of the tooth to support masticatory loads, having an adequate stress distribution over supporting tissues, seems to be decisive when the aim is to obtain a restoration with high fracture resistance.
Bone support and the periodontal ligament are important for the mechanisms of stress distribution over teeth. On in vitro tests, the root embedment material should reproduce bone capacity to absorb masticatory load and thus support the compressive and tangential force in a fracture resistance test. The materials used for root embedment vary greatly: acrylic resin ${ }^{5,12,16}$, die stone $e^{1,4}$ or even polystyrene resin ${ }^{10,11,25}$ can be used. Another important aspect in a fracture resistance test is the simulation of the periodontal ligament. This procedure has been performed with the use of different

\footnotetext{
* Professor, Department of Operative Dentistry and Dental Materials, School of Dentistry, Federal University of Uberlândia.

** Professor, Department of Restorative Dentistry, School of Dentistry, University of Western São Paulo.

*** PhD Student of Dental Materials; ****Professor, Department of Restorative Dentistry - School of Dentistry of Piracicaba, State University of Campinas.
} 
Soares CJ, Pizi ECG, Fonseca RB, Martins LRM. Influence of root embedment material and periodontal ligament simulation on fracture resistance tests. Braz Oral Res 2005;19(1):11-6.

elastomeric materials; however, a great number of in vitro studies have eliminated this procedure ${ }^{4,6,7,8}$. When the periodontal ligament is to be reproduced, it is important to define which material should be used. Elastomeric impression materials have been usually used: some researches used polyether impression material ${ }^{5,22,25}$, other studies recommended the use of a silicone rubber material ${ }^{12,23}$, and other ones employed a polyurethane elastomeric material that was originally created to be used on the fixation of automotive glasse ${ }^{10,11}$. However, there is little discussion about the influence of the properties of specific materials used on the periodontal ligament reproduction on fracture resistance tests and their interaction with the material used for root embedment.

With regard to this situation, it is hypothesized that the periodontal ligament simulation and embedment method can influence the fracture load and mode of the fracture on in vitro fracture tests. Therefore, the aim of this study was to evaluate the importance and influence of both the periodontal ligament reproduction with three different elastomeric materials and the root embedment method with two types of resin on fracture resistance and fracture modes of bovine teeth.

\section{MATERIALS AND METHODS}

Eighty recently extracted bovine incisors with similar dimensions were selected and stored in aqueous $0.2 \%$ thymol solution (F.Maia Ind. Com., Cotia, SP, Brazil). Calculus deposits and soft tissue deposits were removed with periodontal curettes (Hu Friedy, Chicago, IL, USA); then, the teeth were cleaned using a rubber cup (Microdont, São Paulo, SP, Brazil) and fine pumice (Vigodent, RJ, Brazil) water slurry. Teeth were randomly divided into 8 groups $(\mathrm{n}=10)$ for each root embedment method and periodontal ligament simulation. Two types of resin were used: a self-cured acrylic resin (Jet Clássico, São Paulo, SP, Brazil), and a polystyrene resin (Cristal, Piracicaba, SP, Brazil). The teeth were mounted individually in plastic cylinders (Tigre, Rio Claro, SP, Brazil) and the roots were embedded in resin up to $2 \mathrm{~mm}$ below the cementoenamel junction (CEJ). Four methods were used in order to reproduce the periodontal ligament: 1 tooth embedded directly in the resin cylinder; 2 tooth embedded using a polyether impression material (Impregum F, 3M-Espe, Seefeld, Germany); 3 - tooth embedded using a polysulfide impression material (Permlastic, Kerr, Romulus, USA); and 4 tooth embedded using a polyurethane elastomeric material (Ultra flex, Solplas, Santo André, SP, Brazil). Root surfaces were dipped into melted wax (Epoxiglass, Diadema, SP, Brazil) up to $2.0 \mathrm{~mm}$ below the CEJ, resulting in a 0.2 to $0.3 \mathrm{~mm}$ thick wax layer. An X-ray film (Kodak, New York, USA) with a centralized circular hole with $5 \mathrm{~mm}$ in diameter was used to stabilize the teeth for the embedment procedure, $2.0 \mathrm{~mm}$ from the CEJ. This set was positioned downward over a perforated wood plate, and a plastic cylinder with $25.0 \mathrm{~mm}$ in diameter was positioned and fixed with wax. The resins were manipulated according to the manufacturers' instructions and inserted in the cylinder. After resin polymerization, the teeth were removed from the cylinder, and the wax was removed from the root surface and resin cylinder "alveolus". The elastomeric materials were placed in the resin cylinders, the tooth was re-inserted into the cylinder and the excess elastomeric material was removed with a scalpel blade (Xishan Medical Instrument factory, Xishan, China) (Figure 1).

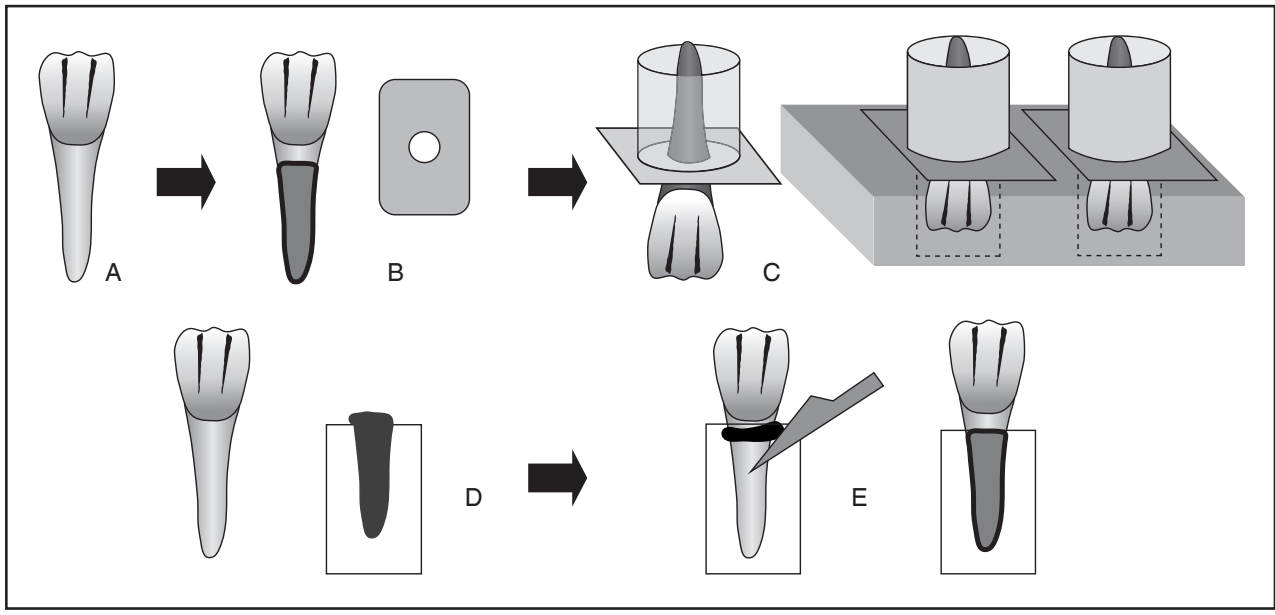

FIGURE 1 - Schematic representation of root embedment and periodontal ligament simulation: (A) bovine incisor tooth; (B) tooth root covered with wax and $\mathrm{X}$-ray film; (C) film and plastic cylinder positioned over a perforated wood plate; (D) tooth without wax removed from the resin cylinder and elastomeric material placed in the resin cylinder; (E) removal of excess elastomeric material and embedment procedure finished. 
Soares CJ, Pizi ECG, Fonseca RB, Martins LRM. Influence of root embedment material and periodontal ligament simulation on fracture resistance tests. Braz Oral Res 2005;19(1):11-6.

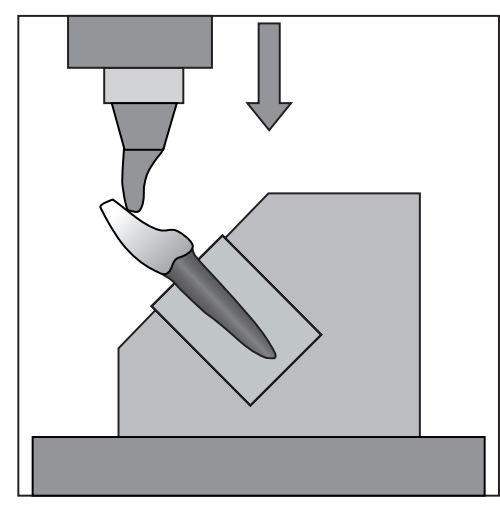

A. Antagonist metallic tooth used in fracture test

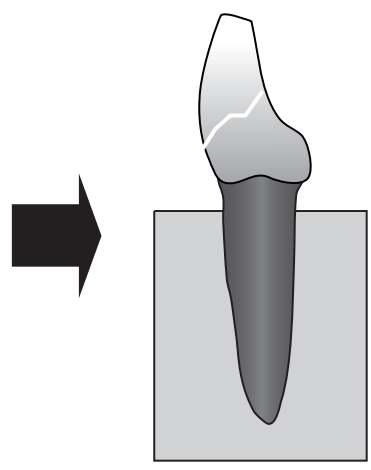

B. Classification of the fracture modes

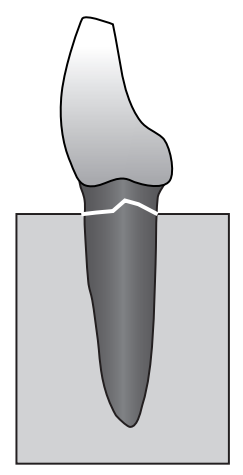

II

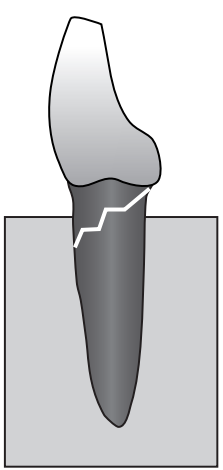

III

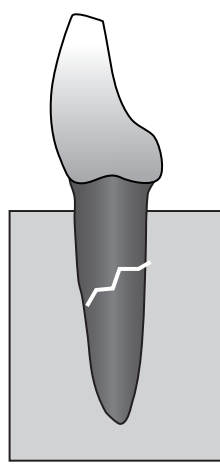

IV

FIGURE 2 - Load application method (A); Classification of the fracture modes (B) - (I) coronal fracture; (II) fracture at the limit of the resin cylinder; (III) fracture with partial invasion of the cylinder insertion; (IV) root fracture.

TABLE 1 - Two-way analysis of variance.

\begin{tabular}{l|r|r|c|c|c}
\hline \multicolumn{1}{c|}{ Source of variation } & DF & Sum of squares & Mean squares & F & p values \\
\hline Resins & 1 & 1.7731 & 1.7731 & 0.0088 & 0.9593 \\
\hline Periodontal ligament & 3 & 1216.8498 & 405.6166 & 2.0049 & 0.0854 \\
\hline Resin versus periodontal ligament & 3 & 3616.8806 & 205.6269 & 5.9593 & $0.0049 * *$ \\
\hline Treatments & 7 & 4835.5034 & 690.7862 & - & - \\
\hline Residual & 72 & 14566.3189 & 202.3100 & - & - \\
\hline \hline
\end{tabular}

** Statistical significance at the level of $5 \%$. DF: degrees of freedom.

TABLE 2 - Means and standard deviations (SD) of fracture load values in kgf.

\begin{tabular}{|c|c|c|}
\hline Resins & Ligament Materials & Means $\pm \mathrm{SD}$ \\
\hline \multirow{4}{*}{ 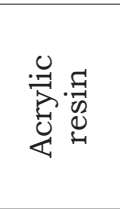 } & Without ligament & $90.91 \pm 13.59^{a}$ \\
\hline & Impregum F (polyether) & $70.39 \pm 13.27^{b}$ \\
\hline & Ultra flex (polyurethane) & $70.23 \pm 10.71^{\mathrm{b}}$ \\
\hline & Permlastic (polysulfide) & $70.19 \pm 11.13^{\mathrm{b}}$ \\
\hline \multirow{4}{*}{ 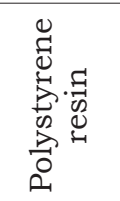 } & Impregum F (polyether) & $95.94 \pm 14.65^{a}$ \\
\hline & Ultra flex (polyurethane) & $72.84 \pm 14.32^{\mathrm{b}}$ \\
\hline & Permlastic (polysulfide) & $72.51 \pm 11.84^{b}$ \\
\hline & Without ligament & $69.24 \pm 21.72^{\mathrm{b}}$ \\
\hline
\end{tabular}

Values with the same letter were not significantly different by Tukey's test $(\mathrm{p}>0.05)$.

The teeth were stored for 24 hours at $37^{\circ} \mathrm{C}$ in $100 \%$ humidity, and then submitted to a tangential load at $0.5 \mathrm{~mm} /$ minute crosshead speed, on a testing machine (Instron 4411, Canton, MA, USA). The antagonistic metallic tooth ( $\mathrm{NiCr}$ alloy, Verabond, Cordelha, USA) was fixed to the universal testing machine and positioned on the incisal third of the lingual surfaces of the teeth (Figure 2A). The load required to fracture the specimens was recorded (kgf) and data were submitted to statistical analysis by two-way ANOVA (Table 1) and Tukey's test $(\alpha=5 \%)$, with two factors being studied: embedment material and periodontal membrane simulation material. The fracture modes were analyzed using the scale shown in Figure 2B.

\section{RESULTS}

Mean values of fracture resistance are described in Table 2. Statistical analysis by two-way ANOVA indicated that there were significant differences only for the interaction between periodontal ligament simulation and root embedment materials (Table 1). Tukey's test revealed statistically significant differences among the groups (Table 2 and Graph 1).

The fracture modes of the specimens are presented in Table 3 . The teeth embedded in acrylic resin or polystyrene resin without periodontal 
Soares CJ, Pizi ECG, Fonseca RB, Martins LRM. Influence of root embedment material and periodontal ligament simulation on fracture resistance tests. Braz Oral Res 2005;19(1):11-6.

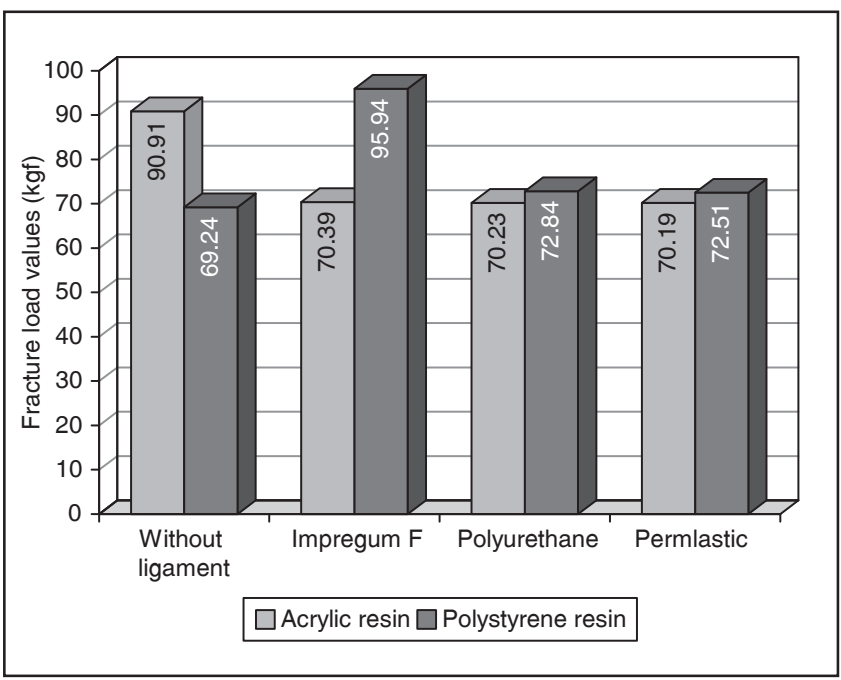

GRAPH 1 - Means of fracture load values in kgf for each of the four types of simulation of periodontal ligament for the two resins used to simulate bone support.

ligament simulation tended to fracture on the top of the resin cylinders, while the teeth with periodontal ligament simulation tended to fracture in different locations with a greater prevalence at the root portion (types III and IV fracture modes).

\section{DISCUSSION}

Teeth can fracture during normal function or traumatic occlusal contacts ${ }^{23}$. Normal function is usually related to low load values, whereas trauma can be related to fast and/or high load values. Tooth fracture resistance is analyzed by in vitro studies through mechanical tests ${ }^{4,6,7,8,14,25}$. Several studies have used compressive and tangential load application over teeth, restorations, posts and prostheses in order to determine their fracture resistance. However, a great number of factors may influence the results, especially if some procedures like mode of load application, crosshead speed, mode of fracture and root embedment method are not standardized. An in vitro test should standardize these factors to better represent a clinical situation.

The periodontal ligament is an important structure for the stress distribution generated by load application over teeth ${ }^{18,22}$. When load is applied, periodontal fibers are compressed, the tooth dislodges slightly and there is bone distortion in the direction of the root movement ${ }^{19}$. The initial resistance of the periodontal fibers against tooth displacement is low. However, as the tooth is forced within its alveolus, the periodontal resistance is progressively increased ${ }^{17}$. When the periodontal fibers achieve maximum load resistance, similar to an hydraulic system, the periodontal membrane gets rigid, the load is transferred to the bone support and the stress is distributed to bone in all root surfaces. The mechanical response of a soft tissue to external stress is non-linear and viscous ${ }^{20}$, which is similar to the characteristics of elastomeric materials used on impression procedures.

Rees $^{21}$ (2001), analyzing the importance of periodontal ligament through a finite element analysis, showed that it is mandatory to include the characteristics of both the periodontal ligament and the alveolar bone in these tests. Isidor et al. ${ }^{12}$ (1996) reported that the simulation of periodontal ligament is essential to determine the stress distributions as similar as possible to the clinical situation, and that a small bar of resin composite at the tip of the embedded roots should be used to create sufficient retention of the mounted roots during load application when a silicone artificial periodontal membrane is used. The tooth remotion from the artificial alveolus was not verified in this study. Sirimai et al. ${ }^{24}$ (1999) reported that it is

TABLE 3 - Fracture modes of the specimens after tangential load tests.

\begin{tabular}{|c|c|c|c|c|c|c|}
\hline \multirow{2}{*}{ Embedment Material } & \multirow{2}{*}{ Ligament type } & \multicolumn{5}{|c|}{ Distribution of fracture modes on specimens } \\
\hline & & I & II & III & IV & Total \\
\hline \multirow{4}{*}{ Polystyrene resin } & Without ligament & 1 & 8 & 1 & - & 10 \\
\hline & Impregum F (polyether) & - & - & 5 & 5 & 10 \\
\hline & Permlastic (polysulfide) & - & 5 & 4 & 1 & 10 \\
\hline & Ultra flex (polyurethane) & - & 3 & 3 & 4 & 10 \\
\hline \multirow{4}{*}{ Acrylic resin } & Without ligament & 2 & 7 & 1 & - & 10 \\
\hline & Impregum F (polyether) & - & 3 & 4 & 3 & 10 \\
\hline & Permlastic (polysulfide) & 1 & 4 & 4 & 1 & 10 \\
\hline & Ultra flex (polyurethane) & - & 4 & 4 & 2 & 10 \\
\hline
\end{tabular}


Soares CJ, Pizi ECG, Fonseca RB, Martins LRM. Influence of root embedment material and periodontal ligament simulation on fracture resistance tests. Braz Oral Res 2005;19(1):11-6.

fundamental to simulate not only the periodontal ligament, but also the tooth supporting structures by means of a root embedment method. However, several studies have ignored the simulation of the periodontal ligament, embedding the tooth directly in a non-resilient resin ${ }^{3}$ because the interposed layer can contribute to mask the influence of the factor in analysis ${ }^{15}$. In this study, the simulation of the periodontal ligament modified considerably the fracture modes, demonstrating that the stress distribution is altered when periodontal ligament is simulated.

There was not a clear difference with regard to the resin type used. Irrespective of the statistical analysis, the means were not greatly different. However, the results demonstrate that more important than the studies based only on fracture load values, which seem to be different from intraoral values observed when teeth are fractured, is the mode of fracture as the principal parameter on a comparative analysis. This factor is currently used to compare different aspects in restorative procedures $^{6,25}$. Soares et al. ${ }^{25}$ (2004) observed higher fracture resistance of teeth restored with indirect resins than of those restored with feldspathic ceramic; however, when the fracture mode was analyzed, they observed that the resin restorations tended to fracture catastrophically, while teeth restored with ceramic tended to show fractures within the restoration.

This study showed a significant difference among the modes of fracture, mainly in relation to the periodontal ligament simulation. When teeth were embedded directly in resin cylinders, stresses seemed to get concentrated around the tooth region localized at the cylinder top. Rigid attachment of the root is not found in nature and may alter the root fracture resistance; this could be clearly seen in the fracture mode analysis. A great number of fractures characterized by failure at the union between the resin cylinder and tooth coronal structure occurred when the periodontal ligament was not simulated. Instead of promoting stress concentration in one particular region, the periodontal ligament transfers the stresses produced by load application over the tooth coronal structure to all root surfaces. This aspect may have a huge importance when the aim, for example, is to analyze the influence of post insertion on tooth fracture resistance, because if the hypotheses that the periodontal ligament can uniformly distribute the stress to all root surfaces is true, this factor can clearly alter the fracture mode produced on in vitro tests. A significant increase in load values was seen in the subgroup of acrylic resin without periodontal ligament simulation. This fact can be explained by the high resilience of this resin, which allows a deformation great enough to absorb the forces.

Ashby, Jones ${ }^{2}$ (1986) stated that the degree of how much cross-linking affects the elastic recovery of the material is similar to the effect of the periodontal ligament in the oral environment when load is applied to the tooth structure. Thus, the elastomeric material type used to simulate the periodontal membrane appears be a secondary factor in fracture resistance tests. The polysulfide material tended to show fracture modes more similar to oral situations than in the group without the use of periodontal ligament simulation. Although it is not commonly used, the polyurethane elastomeric material demonstrated that it can be satisfactorily used to simulate periodontal ligament, principally because it is cheaper than impression materials and produces similar results. The polyether impression material presented a great number of samples with fractures involving root surfaces. These findings can be explained by the results found by Klooster et al. ${ }^{13}$ (1991), who analyzed the physical characteristics of elastomeric impression materials and observed that polysulfide materials exhibited the greatest amount of permanent deformation. Polysulfide materials exhibited lower ultimate tensile strength than polyether materials and the greatest amount of elongation at break, with the highest values occurring at the higher strain rates, showing that the stress is less uniformly transferred to all root surfaces. Based on the facility of usage, consistence, deformation limit and values observed in this study, the polyether material might be the best choice. However, more important than the material used to reproduce the periodontal ligament is the simulation of the periodontal ligament with one of the elastomeric materials.

Every investigation should improve, direct or indirectly, the treatment of patients. In order to connect the result of this study with a clinical situation, the possibility of improving the reality of in vitro studies that investigate the fracture resistance of all-ceramics, inlays, onlays and root posts should be analyzed. Since an in vitro experiment should represent the intra-oral environment, the periodontal ligament must always be simulated. New studies should be conducted to determine both the effect of mode of load application and the apparatus used to support the specimens on a fracture test in order to obtain results of clinical practice importance. 
Soares CJ, Pizi ECG, Fonseca RB, Martins LRM. Influence of root embedment material and periodontal ligament simulation on fracture resistance tests. Braz Oral Res 2005;19(1):11-6.

\section{CONCLUSIONS}

According to the methodology employed in this study and based on the statistical analysis applied to data, it is possible to conclude that:

- A greater influence of periodontal ligament simulation is noted on the fracture mode rather than on the fracture load values.

- The resin type used to embed tooth roots did not have a significant effect on fracture re-

\section{REFERENCES}

1. Al-Wahadni A, Gutteridge DL. An in vitro investigation into the effects of retained coronal dentine on the strength of a tooth restored with a cemented post and partial core restoration. Int Endod J 2002;35:913-8.

2. Ashby MF, Jones DRH. Engineering materials 2: an introduction to microstructures, processing and design. Oxford: Pergamom Press; 1986.

3. Assif D, Bitenski A, Pilo R, Oren E. Effect of post design on resistance to fracture of endodontically treated teeth with complete crowns. J Prosthet Dent 1993;69:36-40.

4. Ausiello P, De Gee AJ, Rengo S, Davidson CL. Fracture resistance of endodontically-treated premolars adhesively restored. Am J Dent 1997;10(5):237-41.

5. Behr M, Rosentrit M, Leidrock A, Shneider-Feyrer S, Handel G. In-vitro study of fracture strength and marginal adaptation of fiber-reinforced adhesive fixed partial inlay dentures. J Dent 1999;27:163-8.

6. Brunton PA, Cattell P, Burke FJ, Wilson NH. Fracture resistance of teeth restored with onlays of three contemporary tooth-colored resin-bonded restorative materials. J Prosthet Dent 1999;82:167-71.

7. Burke FJ, Wilson NH, Watts DC. Fracture resistance of teeth restored with indirect composite resins: the effect of alternative luting procedures. Quintessence Int 1994;25:269-75.

8. Burke FJ, Wilson NH, Watts DC. The effect of cavity wall taper on fracture resistance of teeth restored with resin composite inlays. Oper Dent 1993;18:230-6.

9. Dalpino PH, Francischone CE, Ishikiriama A, Franco EB. Fracture resistance of teeth directly and indirectly restored with composite resin and indirectly restored with ceramic materials. Am J Dent 2002;15:389-94.

10. Dias de Souza GM, Pereira GD, Dias CT, Paulillo LA. Fracture resistance of premolars with bonded class II amalgams. Oper Dent 2002;27:349-53.

11. Dias de Souza GM, Pereira GD, Dias CT, Paulillo LA. Fracture resistance of teeth restored with the bonded amalgam technique. Oper Dent 2001;26:511-5.

12. Isidor F, Odman $\mathrm{P}$, Brondum $\mathrm{K}$. Intermittent loading of teeth restored using prefabricated carbon fiber posts. Int J Prosthodont 1996;9:131-6.

13. Klooster J, Logan GI, Tjan A. Effects of strain rate on the behavior of elastomeric impression. J Prosthet Dent 1991;66:292-8.

14. Mak M, Qualtrough AJE, Burke FJ. The effect of different ceramic materials on the fracture resistance of dentin-bonded crowns. Quintessence Int 1997;28:197-203. sistance values, but considering the fracture mode, root embedment with polystyrene materials tends to show more homogeneous fractures.

\section{ACKNOWLEDGMENTS}

This study was supported by the State of Minas Gerais Research Foundation (FAPEMIG), grant 009/2003, and the Coordination for the Improvement of Higher Education Personnel (CAPES).

15. Martinez-Gonzalez A, Amigo-Borras V, Fons-Font A, Selva-Otaolaurruchi E, Labaig-Rueda C. Response of three types of cast posts and cores to static loading. Quintessence Int 2001;32:552-60.

16. Mezzomo E, Massa F, Libera SD. Fracture resistance of teeth restored with two different post-and-core designs cemented with two different cements: an in vitro study. Part I. Quintessence Int 2003;34(4):301-6.

17. Parfitt GJ. The physical analysis of the tooth supporting structures. In: Anderson DJ, Eastoe JE, Melcher AH, Picton DC. The mechanism of tooth support. Philadelphia: Bristol Wright; 1967. p. 154-68.

18. Picton DC. On the part played by the socket in tooth support. Arch Oral Biol 1965;10:945-55.

19. Picton DC, Davies WI. Dimensional changes in the periodontal membrane of monkeys (Macaca irus) due to horizontal thrusts applied to the teeth. Arch Oral Biol 1967;12:1635-43.

20. Pini M, Wiskott HW, Scherrer SS, Botsis J, Belser UC. Mechanical characterization of bovine periodontal ligament. J Periodontal Res 2002;37:237-44.

21. Rees JS. An investigation into the importance of the periodontal ligament and alveolar bone as supporting structures in finite element studies. J Oral Rehabil 2001;28:425-32.

22. Rosentritt M, Furer C, Behr M, Lang R, Handel G. Comparison of in vitro fracture strength of metallic and tooth-coloured posts and cores. J Oral Rehabil 2000;27:595-601.

23. Salis SG, Hood JA, Kirk EE, Stokes AN. Impact-fracture energy of human premolar teeth. J Prosthet Dent 1987;58:43-8.

24. Sirimai S, Riis DN, Morgano SM. An in vitro study of the fracture resistance and the incidence of vertical root fracture of pulpless teeth restored with six post-and-core systems. J Prosthet Dent 1999;81:262-9.

25. Soares CJ, Martins LR, Pfeifer JM, Giannini M. Fracture resistance of teeth restored with indirect-composite and ceramic inlay sysytems. Quintessence Int 2004;35:281-6.

Received for publication on Dec 17, 2004 Sent for alterations on Feb 11, 2005 Accepted for publication on Mar 17, 2005 